\title{
The effect of supplemental concentrate fed during the dry period on morphological and functional aspects of rumen adaptation in dairy cattle during the dry period and early lactation
}

\author{
K. Dieho, ${ }^{* 1}$ J. Dijkstra, ${ }^{*}$ G. Klop, ${ }^{*}$ J. T. Schonewille, $†$ and A. Banninkł \\ ${ }^{*}$ Animal Nutrition Group, Wageningen University \& Research, PO Box 338, 6700 AH Wageningen, the Netherlands \\ tDepartment of Farm Animal Health, Faculty of Veterinary Medicine, Utrecht University, Yalelaan 7, 3584 CL Utrecht, the Netherlands \\ ¥Animal Nutrition, Wageningen Livestock Research, Wageningen University \& Research, PO Box 338, 6700 AH Wageningen, the Netherlands
}

\begin{abstract}
Ten rumen-cannulated Holstein-Friesian cows were used to examine the effect of feeding supplemental concentrate during the dry period on rumen papillae morphology and fractional absorption rate $\left(k_{\mathrm{a}}\right)$ of volatile fatty acids (VFA) during the dry period and subsequent lactation. Treatment consisted of supplemental concentrate $[3.0 \mathrm{~kg}$ of dry matter $(\mathrm{DM}) / \mathrm{d}]$ from $28 \mathrm{~d}$ antepartum (ap) until the day of calving, whereas control did not receive supplemental concentrate. Cows were fed for ad libitum intake and had free access to the dry period ration (27\% grass silage, $28 \%$ corn silage, $35 \%$ wheat straw, and $11 \%$ soybean meal on a DM basis) and, from calving onward, to a basal lactation ration ( $42 \%$ grass silage, $42 \%$ corn silage, and $16 \%$ soybean meal on a DM basis). From 1 to 3 d postpartum (pp), all cows were fed $0.9 \mathrm{~kg} \mathrm{DM} / \mathrm{d}$ of concentrate, which increased linearly thereafter to $8.9 \mathrm{~kg}$ of DM/d on d $11 \mathrm{pp}$. At 28, 18, and $8 \mathrm{~d}$ ap, and $3,17,31$, and $45 \mathrm{~d}$ pp, rumen papillae were collected and $k_{\mathrm{a}} \mathrm{VFA}$ was measured in all cows. On average, 13.8 (standard deviation: 3.8) papillae were collected each from the ventral, caudodorsal, and caudoventral rumen sacs per cow per day. The $k_{\mathrm{a}} \mathrm{VFA}$ was measured by incubating a standardized buffer fluid (45 L), containing $120 \mathrm{~m} M$ VFA (60\% acetic, $25 \%$ propionic, and $15 \%$ butyric acid) and Co-EDTA as fluid passage marker, in the evacuated and washed rumen. Treatment did not affect ap or pp DM and energy intakes or milk yield and composition. Treatment increased papillae surface area, which was 19 and $29 \%$ larger at 18 and 8 d ap compared with 28 d ap, respectively. Surface area increased, mainly due to an increase in papillae width. However, treatment did not increase $k_{\mathrm{a}} \mathrm{VFA}$ at 18 and $8 \mathrm{~d}$ ap compared
\end{abstract}

Received June 7, 2016.

Accepted September 30, 2016.

${ }^{1}$ Corresponding author: kasper.dieho@wur.nl with $28 \mathrm{~d}$ ap. In the control group, no changes in papillae surface area or $k_{\mathrm{a}} \mathrm{VFA}$ were observed during the dry period. In the treatment group, papillae surface area decreased between $8 \mathrm{~d}$ ap and $3 \mathrm{~d} \mathrm{pp}$, whereas no decrease was observed for control. From 3 to $45 \mathrm{~d}$ $\mathrm{pp}$, papillae surface area and $k_{\mathrm{a}} \mathrm{VFA}$ increased for all cows by approximately $50 \%$, but the ap concentrate treatment did not affect $k_{\mathrm{a}} \mathrm{VFA}$ pp. In conclusion, the efficacy of supplemental concentrate during the dry period to increase papillae surface area and $k_{\mathrm{a}} \mathrm{VFA}$ in preparation for subsequent lactation is not supported by the present study. Current observations underline the importance of functional measurements in lieu of morphological measurements to assess changes in the adapting rumen wall.

Key words: transition dairy cow, rumen adaptation, rumen papillae, rumen epithelium, volatile fatty acid absorption

\section{INTRODUCTION}

After calving, fermentable organic matter (FOM) intake of cows increases rapidly, resulting in a more than 2 -fold increase in the production of VFA at maximal feed intake postpartum (Bergman, 1990). To maintain ruminal conditions favorable for fermentation, buffering and clearance of the produced VFA is essential (Penner et al., 2009; Aschenbach et al., 2011; Dijkstra et al., 2012). Clearance of VFA from the rumen is the result of either passage or absorption across the rumen epithelium (Gäbel et al., 2002; Aschenbach et al., 2011). Earlier work has shown that the rate of absorption of VFA depends on the $\mathrm{pH}$ of the rumen fluid, on the concentration and type of VFA (Thorlacius and Lodge, 1973; Dijkstra et al., 1993), and on the surface area of the rumen papillae (Dirksen et al., 1984; Melo et al., 2013).

Increased FOM intake results in an increase in VFA production and thereby in a proliferation of the rumen papillae and epithelium, through a direct effect on 
cell mitosis and apoptosis (Mentschel et al., 2001) and through growth factors of, for example, the IGF axis (Steele et al., 2015). Although growth can be rapid, the process of proliferation may take several weeks to complete (Dirksen et al., 1985; Bannink et al., 2012; Dieho et al., 2016a). It can be hypothesized that a mismatch between the rate of increase in VFA production and development of the papillae is a factor underlying problems with maintaining optimal rumen conditions for fermentation during early lactation (Dirksen et al., 1985; Krause and Oetzel, 2006; Aschenbach et al., 2011). Stimulation of the surface area of rumen papillae during the dry period may be an effective strategy to prevent high VFA concentrations and concomitant low pH rumen during early lactation (Liebich et al., 1987). However, an increase in papilla surface area does not necessarily result in a concomitant increase in fractional rate of VFA absorption (Dieho et al., 2016b). This finding casts doubt on the efficacy of increasing papillae surface area on VFA absorption capacity in the late dry period. In addition, to date, the efficacy of increasing papilla surface area during the late dry period on VFA absorption capacity during early lactation has not been supported by in vivo measurements.

The aim of the present experiment was therefore to examine the effect of feeding supplemental concentrate during the last 4 wk of the dry period on rumen papillae morphology and fractional absorption rate of VFA $\left(\boldsymbol{k}_{\mathrm{a}}\right.$ VFA $)$ during the dry period and early lactation. Feeding supplemental concentrate during the dry period was expected to increase papillae surface area and $k_{\mathrm{a}} \mathrm{VFA}$ in that period and to positively affect surface area and $k_{\mathrm{a}} \mathrm{VFA}$ in the early weeks of subsequent lactation.

\section{MATERIALS AND METHODS}

The experimental procedures were approved by the Animal Care and Ethics Committee of Wageningen University \& Research (Wageningen, the Netherlands) and conducted under the Dutch Law on Animal Experiments.

\section{Animals, Experimental Design, and Management}

Nine weeks before the expected calving date, $10 \mathrm{ru}-$ men-cannulated (10 cm i.d., Bar Diamond Inc., Parma, ID; cannulated during the first lactation) HolsteinFriesian dairy cows [second $(\mathrm{n}=8)$ and fourth $(\mathrm{n}=$ 2) lactation] entered the randomized block design with repeated measurements experiment. Cows were paired based on parity, expected calving date, and milk yield of the previous lactation. Within pairs, cows were randomly assigned to either a control $(\mathbf{C O N}, \mathrm{n}=5)$ or a supplemental concentrate treatment group (SUP, $\mathrm{n}=$ 5). Samples were collected 28,18 , and $8 \mathrm{~d}$ antepartum (ap), and at 3, 17, 31, and 45 d postpartum (pp). Dry and lactating animals were housed in separate groups in a freestall barn with a slatted concrete floor. Stalls were fitted with rubber mattresses covered with sawdust. On sampling days, before morning feeding, cows were moved to a tiestall at $\sim 0830 \mathrm{~h}$ for the experimental procedures. Cows were milked at 0530 and 1530 h. Milk production was recorded at each milking and, each week, samples from 4 consecutive milkings (same days every week) were analyzed for fat and protein contents (ISO, 1999; Qlip NV, Zutphen, the Netherlands). During the dry period, cows were weighed at weekly intervals, and during lactation, BW was automatically recorded in the milking parlor.

\section{Rations and Chemical Analyses}

Throughout the dry period, all cows had free access to the dry period ration (Table 1 ). From $28 \mathrm{~d}$ ap onward, the cows allocated to SUP were fed $3 \mathrm{~kg} D M / d$ of supplemental concentrate. From the day of calving onward, all cows had free access to the lactation ration (Table 1), and daily concentrate allowances were identical for both treatment groups. All cows were fed for ad libitum intake (minimum 10\% refusals). From calving to $3 \mathrm{~d} \mathrm{pp}$, cows received $0.9 \mathrm{~kg} \mathrm{DM} / \mathrm{d}$ of concentrate. Thereafter, concentrate allowance increased at a rate of $1.0 \mathrm{~kg}$ of $\mathrm{DM} / \mathrm{d}$ to a maximum of $8.9 \mathrm{~kg}$ of $\mathrm{DM} / \mathrm{d}$ on $11 \mathrm{~d}$ pp. The maximum concentrate allowance was maintained until the end of the experiment. Concentrate composition (Table 1) did not differ for the ap and pp periods. Daily intake $(\mathrm{kg} / \mathrm{d})$ of the rations was measured individually using computerized feed bins with automatic weighing (Insentec, Marknesse, the Netherlands). Maximum stocking density was 2 cows per feed bin, with cows having access to all feed bins. Feed was prepared daily and fed at 1000 h. All cows had free access to water throughout the experiment. The individual daily concentrate allowance was made available in equal portions over six 4-h periods using a concentrate dispenser (Manus VC5, DeLaval, Steenwijk, the Netherlands). During the visits, concentrate was fed in a series of small portions and cows were shielded from herdmates, effectively preventing other cows stealing concentrate. Roughage and concentrate samples were taken once a week, stored at $-20^{\circ} \mathrm{C}$ pending analysis, and analyzed as described by Dieho et al. (2016a). Additional weekly roughage samples were used for determination of DM content by forced-air oven drying. If necessary, the basal ration formulation (on a product basis) was adjusted for changes in ration ingredient DM content. 


\section{Collection of Rumen Papillae and Measurements}

During all sampling days, the rumen evacuation and papillae collection and processing were performed as described by Dieho et al. (2016a). Briefly, a rumen fluid sample was taken from the ventral rumen sac between 0.5 and $3 \mathrm{~h}$ (average $1 \mathrm{~h}$ ) after last access to feed to determine $\mathrm{pH}$ and VFA concentration. Thereafter, rumen contents were completely evacuated and stored in a covered, insulated tub. Then, the rumen was washed twice with $10 \mathrm{~L}$ of tap water at $39^{\circ} \mathrm{C}$. Subsequently, papillae were collected from the ventral rumen sac (VRS), the caudoventral blind rumen sac (VBS), and caudodorsal blind rumen sac (DBS). An average of 13.8 (SD 3.8; minimum of 8) intact papillae per site per cow per sampling day were collected. Collected papillae were gently rinsed in $0.9 \% \mathrm{NaCl}$ and stored in buffered $4 \%$ formaldehyde solution pending processing.

Macroscopic measurements on digital photographs of the papillae (one-sided surface area, length, and width) were made as described by Dieho et al. (2016a). Briefly, all papillae (per site per cow per sampling day) were photographed (Casio Exilim EX-Z70, Casio Computer Co., Tokyo, Japan), including a ruler in each photograph. The surface area of all papillae was measured using the "Analyze Particles" feature of ImageJ (version 1.44n, National Institutes of Health, Bethesda, MD). Length (tip to base) and width (measured at the halfway point of the tip-to-base length) of all papillae was measured using ImageScope (version 11.2.0.780, Aperio Technologies, Leica Biosystems, Nußloch, Germany). Total papilla surface area was calculated as $2 \times$ onesided surface area as measured.

Five papillae per site per cow per sampling day (in line with Odongo et al., 2006; Steele et al., 2015; Dieho et al., 2016a) were processed for histology (minimum of 3 wk after collection and storage in buffered $4 \%$ formaldehyde) and digitized, and measurements of papillae and epithelium thickness were made, as adapted from Dieho et al. (2016a). Briefly, total thickness of the papilla and thickness of the interstitium (both measured perpendicular to papilla length) were measured at $250,500,750,1,000$, and $1,250 \mu \mathrm{m}$ from the tip of the papillae, and 5 times at approximately half of the papilla length at $250-\mu \mathrm{m}$ intervals over a total length of $1,000 \mu \mathrm{m}$, using ImageScope (version 11.2.0.780, Aperio Technologies). Papillae and epithelium thicknesses measured at the tip and halfway the papillae length were averaged.

\section{Measurement of Fractional Absorption Rate of VFA}

The fractional absorption rate of VFA was measured using a buffer incubation technique (BIT) in an empty
Table 1. Basal ration composition, nutritional value and chemical composition of rations and concentrate $(\mathrm{g} / \mathrm{kg}$ of DM unless stated otherwise)

\begin{tabular}{|c|c|c|c|}
\hline \multirow[b]{2}{*}{ Item } & \multicolumn{2}{|c|}{ Basal ration } & \multirow[b]{2}{*}{ Concentrate $^{1}$} \\
\hline & Dry-period & Lactation & \\
\hline \multicolumn{4}{|l|}{ Ingredients } \\
\hline Grass silage $^{2}$ & 270 & 416 & \\
\hline Corn silage $^{2}$ & 278 & 424 & \\
\hline Soybean meal & 107 & 160 & \\
\hline Wheat straw & 345 & 0 & \\
\hline \multicolumn{4}{|l|}{ Chemical composition } \\
\hline DM, g/kg of product & 503 & 409 & 890 \\
\hline Crude ash & 81 & 78 & 70 \\
\hline $\mathrm{CP}$ & 109 & 151 & 162 \\
\hline Crude fat & 21 & 32 & 23 \\
\hline Starch & 111 & 165 & 201 \\
\hline Sugar & 41 & 60 & 137 \\
\hline NDF & 531 & 394 & 212 \\
\hline $\mathrm{ADF}$ & 331 & 240 & 126 \\
\hline $\mathrm{ADL}$ & 35 & 17 & 16 \\
\hline \multicolumn{4}{|l|}{ Calculated value $^{3}$} \\
\hline $\mathrm{NE}_{\mathrm{L}}, \mathrm{MJ} / \mathrm{kg}$ of $\mathrm{DM}$ & 5.3 & 6.6 & 7.5 \\
\hline IDP & 56 & 87 & 103 \\
\hline RDPB & 3 & 13 & 1 \\
\hline FOM & 476 & 547 & 685 \\
\hline
\end{tabular}

${ }^{1}$ Concentrate composition (ingredients, $\mathrm{g} / \mathrm{kg}$ of DM): sugar beet pulp, 214; corn gluten, 211; barley, 175; citrus pulp, 160; wheat, 69; rapeseed meal, 63; soybean meal, 56; molasses, 40; salt, 7; $\mathrm{CaCO}_{3}, 3$; and mineral premix, 2.

${ }^{2}$ Chemical composition of grass silage ( $/ \mathrm{kg}$ of DM): crude ash, 111 ; CP, 102; crude fat, 36; sugar, 96; NDF, 525; ADF, 326; and ADL, 19.

Chemical composition of corn silage ( $\mathrm{g} / \mathrm{kg}$ of $\mathrm{DM})$ : crude ash, 50; CP, 68; crude fat, 31; starch, 382; NDF, 377; ADF, 217; and ADL, 20.

${ }^{3}$ Calculated values for grass and corn silage based on near-infrared spectrometry (Blgg AgroXpertus, Wageningen, the Netherlands). Calculated values for soybean meal and concentrate provided by Agrifirm Feed (Apeldoorn, the Netherlands). Calculated values for wheat straw obtained from CVB Feed Tables (CVB, 2011). NE $E_{\mathrm{L}}$ values were calculated according to the Dutch NE-system (van Es, 1978). $\mathrm{IDP}=$ intestinal digestible protein; $\mathrm{RDPB}=\mathrm{RDP}$ balance; $\mathrm{FOM}=$ fermentable OM; all calculated according to the Dutch DVE/OEBsystem (Tamminga et al., 1994).

washed rumen. The BIT procedure, buffer fluid composition, sample processing, and analysis was described in detail in Dieho et al. (2016b). Briefly, 50.0 L of standardized buffer fluid at $39^{\circ} \mathrm{C}$ and $\mathrm{pH} 5.9$, containing $120 \mathrm{~m} M$ VFA $[60 \%$ acetic (Ac), $25 \%$ propionic $(\mathbf{P r})$, and $15 \%$ butyric $(\mathbf{B u})$ acid] and $0.17 \mathrm{~m} M$ Co-EDTA as fluid passage marker (Udén et al., 1980), was prepared immediately before use. After the rumen evacuation and collection of rumen papillae as described above, 5.0 $\mathrm{L}$ of buffer fluid was used to wash the rumen wall. All fluid was subsequently removed from the rumen using a vacuum system, followed by introduction of the remaining $45.0 \mathrm{~L}$ of buffer fluid. After $60 \mathrm{~min}$, the remaining fluid was completely recovered using the vacuum system and weighed. Thereafter, rumen contents were returned to the respective cow. For determination of $\mathrm{pH}$ and VFA concentrations, buffer fluid was sampled im- 
mediately before introduction into the rumen and after 60 min of incubation in the rumen. Concentration of VFA in rumen and buffer fluid was determined by GC using hydrogen as carrier gas, and the concentration of Co in the buffer fluid was determined by atomicabsorption spectrophotometry (Dieho et al., 2016b). The fractional absorption rate $\left(\boldsymbol{k}_{\mathrm{a}}, / \mathrm{h}\right)$ of Ac $\left(\boldsymbol{k}_{\mathrm{a}} \mathbf{A c}\right)$, $\operatorname{Pr}\left(\boldsymbol{k}_{\mathrm{a}} \mathrm{Pr}\right)$, and $\mathrm{Bu}\left(\boldsymbol{k}_{\mathrm{a}} \mathrm{Bu}\right)$, and the fractional fluid passage rate $\left(\boldsymbol{k}_{\mathbf{l}}, / \mathrm{h}\right)$ were calculated as described by Dijkstra et al. (1993).

\section{Blood Sampling and Analysis}

Before starting the evacuation of the rumen contents, blood samples were collected from the tail vein using a vacuum sample tube (Vacuette, Greiner BioOne, Kremsmünster, Austria) containing either NaF for glucose, or heparin for nonesterified fatty acids (NEFA) and BHB. Immediately after collection, samples were stored on ice for a maximum of $3 \mathrm{~h}$ before centrifuging $(10 \mathrm{~min}$ at $3,000 \times \mathrm{g})$. Blood plasma aliquots were stored at $-20^{\circ} \mathrm{C}$ pending analysis of glucose, NEFA, and BHB concentration by the Veterinary Diagnostic Laboratory (Utrecht University, the Netherlands) as described by van Knegsel et al. (2007).

\section{Statistical Analysis}

All variables were assumed related to sampling day and treatment. For each sampling day, the reported DMI and nutrient intake are the averages of intakes recorded during the 3 preceding days. All morphological measurements were averaged per site per cow per sampling day before statistical analysis. Data describing rumen papillae were analyzed using the MIXED procedure (Littell et al., 2006) in SAS (version 9.3; SAS Institute Inc., Cary, NC) with the model

$$
Y_{i j k l}=\mu+T_{i}+S_{k}+D_{l}+(T \times D)_{i l}+D(C)_{j l}+e_{i j k l},
$$

where variable $Y_{i j k l}$ was dependent on $\mu$ as the average experimental value and fixed main effects of concentrate treatment $T_{i}(i=\mathrm{CON}, \mathrm{SUP})$, sampling day $D_{l}$ $(l=-28, \ldots, 45)$, site $S_{k}(k=\mathrm{VRS}, \mathrm{VBS}, \mathrm{DBS})$, and interaction $(T \times D)_{i l}$. Random effects of sampling day within cows $D(C)_{j l}$ were included, avoiding pseudoreplication due to multiple biopsy sites $S_{k}$. Errors $e_{i j k l}$ were assumed to be auto-correlated for repeated observations on the same cow and site, using a spatial power covariance structure over sampling days (Littell et al., 1998). All other data for which sampling site within the rumen was not applicable were analyzed with a reduced model by removing $S_{k}$ and $D(C)_{j l}$ and with repeated measurements on the same cow (Dieho et al., 2016b). Where appropriate, $D_{l}$ was replaced by $W e e k_{l}$. Contrast statements were constructed for testing the (1) effect of dry period versus lactation; (2) treatment main effect, $T_{i}$ (averaged over sampling days); (3) sampling day main effect, $D_{l}$ (averaged over treatments); and (4) interaction between treatment and sampling day, $(T$ $\times D)_{i l}$. Treatment effects on individual sampling days were tested using the SLICE option when an interaction $(T \times D)_{i l}$ was observed. All morphological papillae variables are reported as the least squares means of the 3 sampling sites for each treatment and sampling day combination. All results are reported as least squares means with standard errors unless indicated otherwise. Significance of effect was declared at $P<0.05$ and trends at $0.05 \leq P<0.10$.

\section{RESULTS}

Nine out of 10 cows completed the experiment successfully. One cow (SUP) calved earlier than expected (stillbirth), and missed sampling at $8 \mathrm{~d}$ ap. This cow was treated for retained fetal membranes, endometritis, and subsequently for a displaced abomasum that required surgery. At this point, the cow was removed from the experiment to aid recovery. All data relating to this cow were excluded from the analysis. Four other cows received veterinary treatment. One cow was treated for coliform mastitis (CON), 2 for (chronic) endometritis (both CON), and 1 for ketosis (SUP). These animals reacted favorably to treatment and completed the experiment as planned. Average (SD) actual sampling days were $29.1(1.8), 18.9(2.0)$, and $8.6(1.9) \mathrm{d}$ ap, and $3.2(0.4), 17.7(1.0), 31.3(0.5)$, and $45.6(1.3) \mathrm{d}$ pp. No difference in actual sampling days was detected between CON and SUP $(P=0.85)$.

\section{Feed Intake, Production, BW, and Blood Metabolites}

The daily allowances of the supplemental concentrate were completely consumed during the dry period. Total DMI (Table 2; Figure 1A) increased from, on average, $12.2 \mathrm{~kg} / \mathrm{d}$ during the dry period to $22.3 \mathrm{~kg} / \mathrm{d}$ at $45 \mathrm{~d} \mathrm{pp}$ $(P<0.01)$. No interaction between treatment and sampling day $(P=0.58)$ was observed for DMI, and it was similar for CON and SUP throughout the experimental period $(P=0.56)$. Basal ration DMI was numerically lower from $18 \mathrm{~d}$ ap to $3 \mathrm{~d}$ pp in SUP $(9.2 \mathrm{~kg} / \mathrm{d})$ than in CON $(11.8 \mathrm{~kg} / \mathrm{d})$, but neither an effect of treatment $(P=0.14)$ nor an interaction between treatment and sampling day $(P=0.78)$ was observed. Despite the greater contents of FOM, starch, sugar, and $\mathrm{NE}_{\mathrm{L}}$, and lesser content of NDF in the concentrate versus the basal dry period ration, only the intake of sugar was 
Table 2. Least squares means of feed intake $^{1}(\mathrm{~kg} / \mathrm{d}$ unless otherwise noted) for the control (no concentrate during the dry period; CON, $\mathrm{n}=5$ ) and supplemental concentrate treatment $\left(3.0 \mathrm{~kg}\right.$ of DM/d concentrate during the dry period; SUP, $\left.\mathrm{n}=4^{2}\right)$

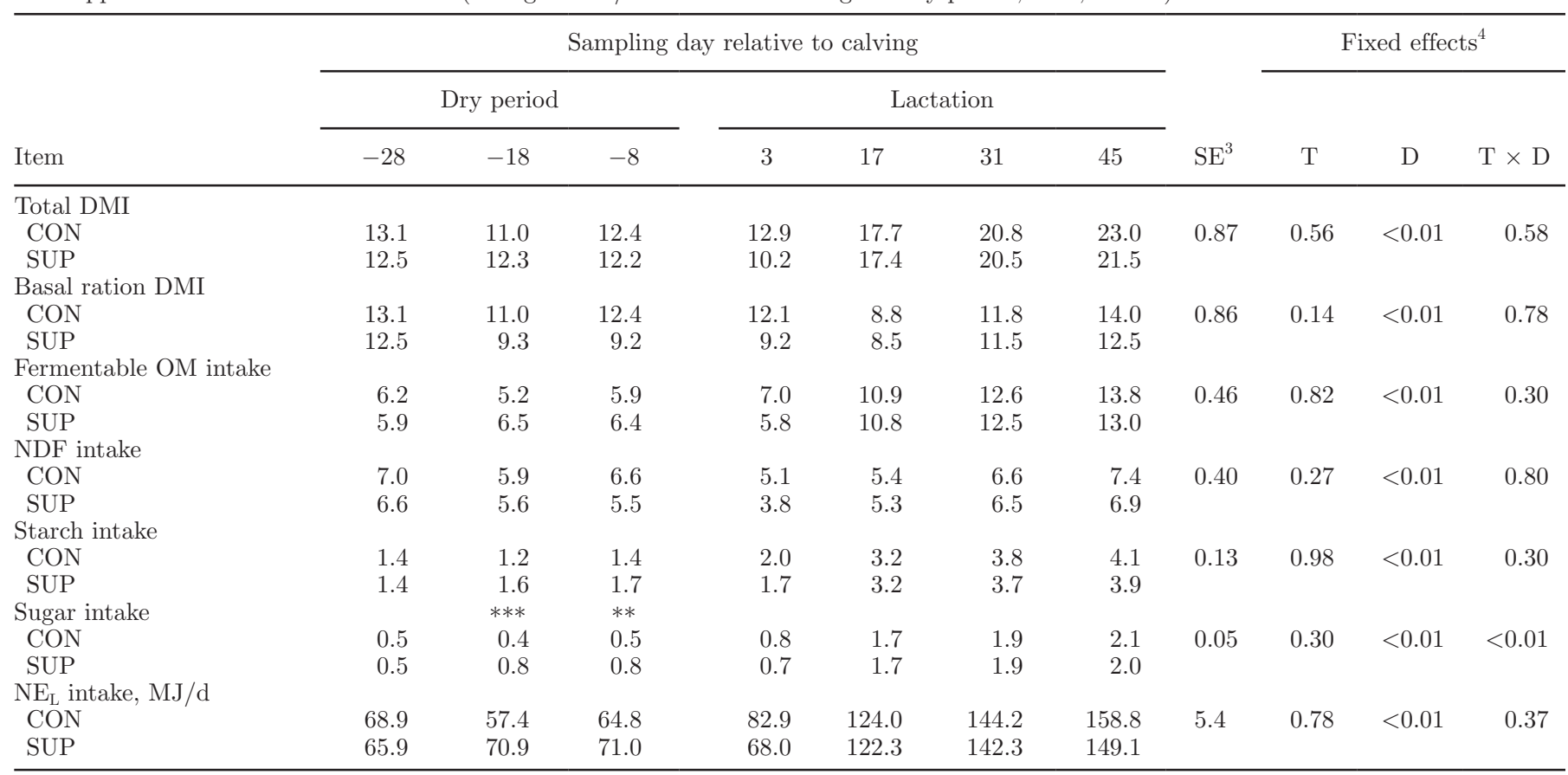

${ }^{1}$ Reported mean is calculated over the $3 \mathrm{~d}$ preceding the sampling day.

${ }^{2}$ Group SUP: $\mathrm{n}=4$ ( 1 cow was removed from the experiment).

${ }^{3} \mathrm{SE}$ for LSM by sampling day; $\mathrm{n}=9$.

${ }^{4} \mathrm{~T}=$ treatment $\mathrm{D}=$ sampling day; $\mathrm{T} \times \mathrm{D}=$ interaction between treatment and sampling day.

${ }^{* *} P<0.01,{ }^{* * *} P<0.001$, significance of difference in LSM of CON and SUP for the same sampling day and variable.

affected. For sugar intake, we observed an interaction between treatment and sampling day $(P<0.01)$, with approximately double intake for SUP $(0.8 \mathrm{~kg} / \mathrm{d})$ compared with CON $(0.5 \mathrm{~kg} / \mathrm{d})$ at 18 and $8 \mathrm{~d}$ ap. During lactation, daily intake of $\mathrm{NE}_{\mathrm{L}}$ increased from $66.5 \mathrm{MJ} / \mathrm{d}$ during the dry period to $154.0 \mathrm{MJ} / \mathrm{d}$ at $45 \mathrm{~d}$ pp $(P<$ 0.01). Total DMI and intakes of FOM, starch, sugar, and $\mathrm{NE}_{\mathrm{L}}$ were greater during lactation compared with the dry period $(P<0.01)$, whereas intakes of basal ration and NDF were similar during the dry period and lactation $(P \geq 0.37)$.

The intake of supplemental concentrate during the dry period had no effect on subsequent milk yield or milk composition. Daily milk production (Figure 1A) increased from wk 1 to 7 from an average of 29.3 to 47.4 $\pm 1.86 \mathrm{~kg} / \mathrm{d}(P<0.01)$, but we observed neither a carryover effect of treatment $(P=0.59)$ nor an interaction between treatment and week $(P=0.98)$. The milk fat and protein contents (Figure 1B) were not affected by treatment $(P \geq 0.27)$ and we did not detect an interaction between treatment and week $(P \geq 0.21)$. Daily milk yield expressed as fat- and protein-corrected milk did not show differences between CON and SUP (data not shown).
Body weight (Figure 2) was not affected by treatment $(P=0.67)$, and no interaction between treatment and week was observed $(P=0.97)$. Body weight did not change during the dry period $(P=0.15)$, averaging $816 \pm 25.6 \mathrm{~kg}$. After calving, BW decreased from 737 $\pm 25.6 \mathrm{~kg}$ during wk $1 \mathrm{pp}$ to $698 \pm 25.6 \mathrm{~kg}$ during wk 7 pp $(P<0.01)$.

Blood glucose (Table 3) was not affected by treatment or sampling day, and we found no interaction between treatment and sampling day $(P \geq 0.32)$. Blood glucose was higher during the dry period compared with lactation $(P<0.01)$. In contrast, NEFA and BHB concentrations were higher during the lactation compared with the dry period $(P<0.01)$. Mean NEFA and BHB concentrations increased $(P \leq 0.01)$ from 0.30 and $0.53 \mathrm{~m} M$ during the dry period to peak values of 1.43 and $1.16 \mathrm{mM}$ at $3 \mathrm{~d} \mathrm{pp}$, respectively. We detected no interactions between treatment and sampling day for either blood NEFA or BHB $(P \geq 0.21)$.

\section{Morphological Changes of the Rumen Papillae}

Papillae surface area (Table 4) changed during the experimental period $(P<0.01)$ and was greater during 
lactation than the dry period $(P<0.01)$. An interaction between treatment and sampling day was observed $(P=0.04)$. Papillae surface area increased by $10.1 \mathrm{~mm}^{2}$ from 28 to $8 \mathrm{~d}$ ap $(P<0.01)$ for SUP but subsequently decreased by $6.9 \mathrm{~mm}^{2}$ between $8 \mathrm{~d}$ ap and $3 \mathrm{~d}$ pp $(P=$ 0.02). Papillae surface area for CON remained similar during the dry period $(P=0.64)$ and did not change from $8 \mathrm{~d}$ ap to $3 \mathrm{~d}$ pp $(P=0.37)$. During lactation, from 3 to $45 \mathrm{pp}$, papillae surface area increased by 51 and $43 \%$ for CON and SUP $(P<0.01)$, respectively. An interaction between treatment and sampling day was
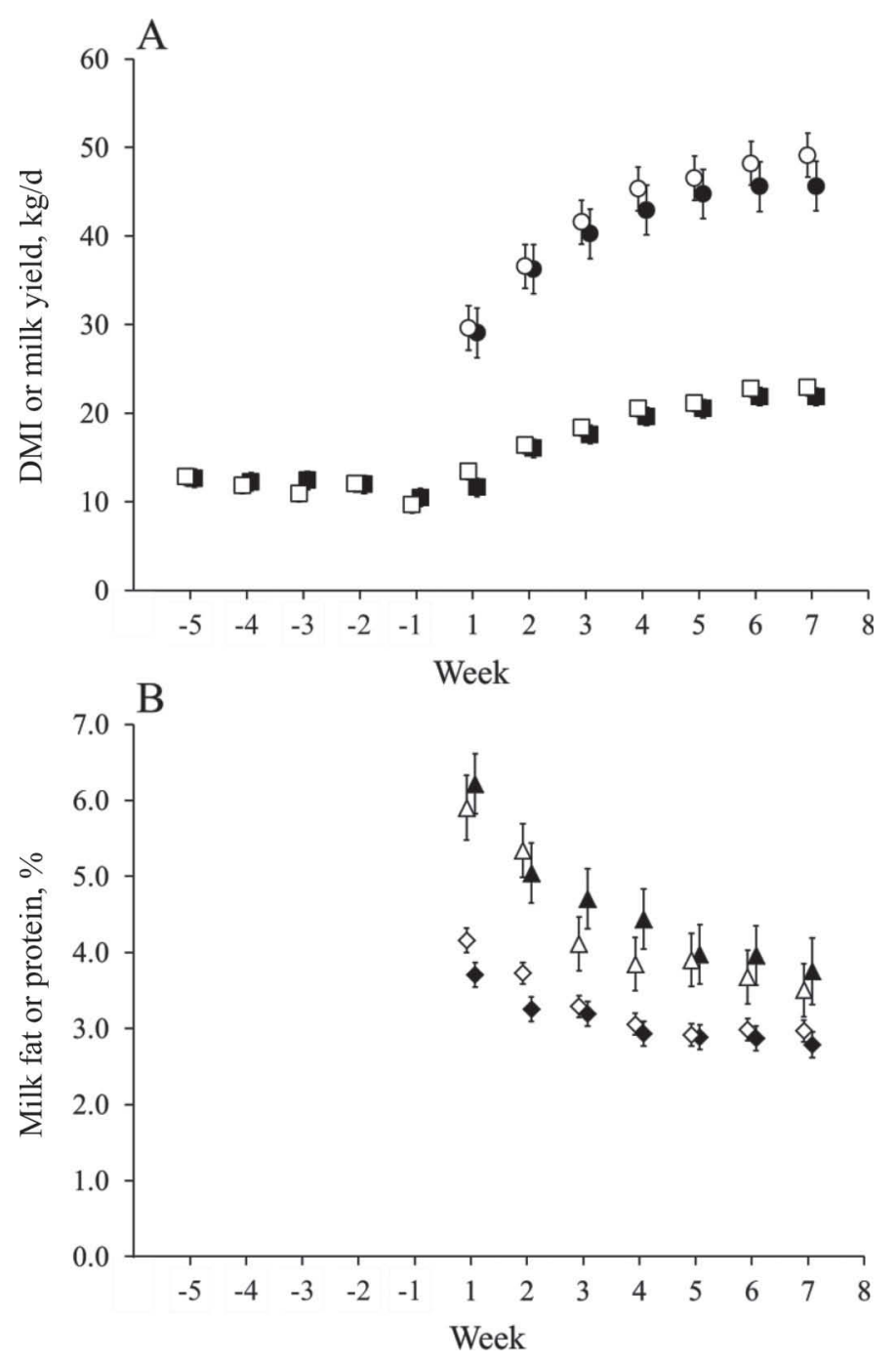

Figure 1. (A) Weekly average of DMI ( $\square \mathbf{\square})$ and daily milk production $(\mathrm{O})$, and $(\mathrm{B})$ weekly average of milk fat $(\Delta \mathbf{\Lambda})$ and milk protein $(\diamond \diamond)$ content of 4 consecutive milking sessions for the control (no concentrate during the dry period; open symbols, $\mathrm{n}=5$ ) and for the dry period treatment with supplemental concentrate $(3.0 \mathrm{~kg}$ of DM/d concentrate during the dry period; solid symbols, $\mathrm{n}=4)$, and the subsequent lactation period. Values represent LSM $\pm \mathrm{SE}$ (values are slightly offset for clarity).

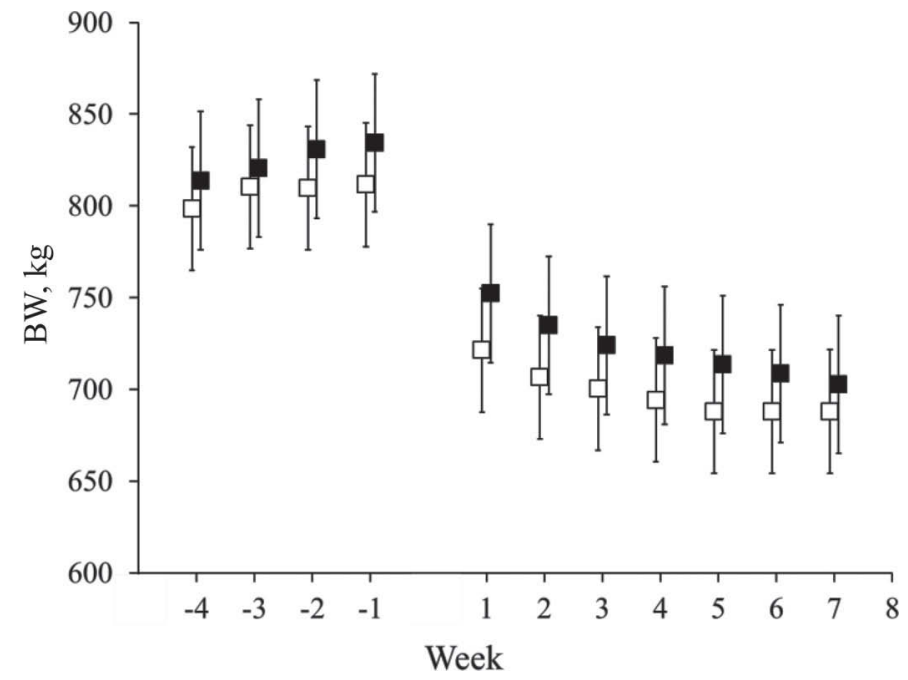

Figure 2. Weekly average of BW for the control (no concentrate during the dry period; $\square, \mathrm{n}=5$ ) and for the dry period treatment with supplemental concentrate $(3.0 \mathrm{~kg}$ of $\mathrm{DM} / \mathrm{d}$ concentrate during the dry period; $\mathbf{\square}, \mathrm{n}=4$ ), and the subsequent lactation period. Values represent LSM $\pm \mathrm{SE}$ (values are slightly offset for clarity).

observed $(P=0.03)$ for the change in papillae surface area relative to $28 \mathrm{~d}$ ap. Papillae surface area increased for SUP at 18 and $8 \mathrm{~d}$ ap, whereas a numerical decrease was observed for CON on these sampling days. These differences in papillae development between treatment groups disappeared from $3 \mathrm{~d}$ pp onward. Changes in papillae surface area during lactation were greater than those during the dry period $(P<0.01)$. Changes in papillae surface differed between sites $(P=0.01)$. The greatest changes in surface area were observed for the DBS, mainly during lactation. Surface area in the DBS increased, on average, $10.6 \mathrm{~mm}^{2}$ from 3 to $45 \mathrm{~d} \mathrm{pp}$, compared with 5.6 and $4.6 \mathrm{~mm}^{2}$ for the VRS and VBS $(P \leq 0.02)$, respectively. Changes in papillae surface area were similar in the VRS and VBS $(P=0.61)$.

Papillae length was affected by sampling day $(P<$ 0.01 ) and was greater during lactation than during the dry period $(P<0.01)$. It also tended to increase between 28 and $8 \mathrm{~d}$ ap in SUP $(P=0.05)$ but not in CON $(P$ $=0.35)$. After calving, papillae length increased $(P<$ $0.01)$. The length of papillae differed $(P=0.02)$ for the sites, with an average length of 9.6, 9.1, and $8.4 \mathrm{~mm}$ for the VRS, VBS, and DBS, respectively. Papillae width was affected by sampling day $(P<0.01)$, treatment $(P$ $<0.01$ ), and the interaction between treatment and sampling day $(P<0.01)$ and width was greater during lactation than the dry period $(P<0.01)$. Papillae width was greater in CON at $28 \mathrm{~d}$ ap than in SUP. However, at 18 and $8 \mathrm{~d}$ ap and at $3 \mathrm{~d} \mathrm{pp}$, this difference disappeared and returned from $17 \mathrm{~d}$ onward. Compared with $28 \mathrm{~d}$ ap, papillae width had increased by $24 \%$ 
in SUP by $8 \mathrm{~d}$ ap, whereas no changes in width were observed in CON.

Papillae were generally thicker for CON than for SUP $(P=0.01)$, and thickness was affected by sampling day $(P<0.01)$, showing a temporary peak at 17 $\mathrm{d}$ pp. An interaction between treatment and day was observed $(P=0.04)$ and papillae were thinner at 18 and $8 \mathrm{~d}$ ap and $3 \mathrm{~d}$ pp in SUP compared with CON. In contrast to thickness of the complete papillae, thickness of the epithelial layer was not affected by sampling day $(P=0.15)$ and we observed no interaction between treatment and sampling day $(P=0.19)$. Thickness of the epithelium was greater, on average, for CON than for SUP $(P=0.02)$. Papillae thickness and epithelium thickness were similar during the dry period and lactation $(P \geq 0.49)$

\section{Rumen Fluid Composition and Fractional VFA Absorption Rate}

An interaction between treatment and sampling day $(P \leq 0.03)$ was observed for total VFA concentration in, and $\mathrm{pH}$ of, the rumen fluid (Figure 3A). At $18 \mathrm{~d}$ ap, total VFA concentration was $33 \mathrm{~m} M$ higher $(P<$ $0.01)$ for SUP $(120 \pm 5.5 \mathrm{~m} M)$ compared with CON (87 $\pm 5.5 \mathrm{mM}$ ). For SUP, total VFA concentration subsequently decreased $(P=0.02)$ to a nadir $(91 \pm 5.5 \mathrm{mM})$ at $3 \mathrm{~d} \mathrm{pp}$, whereas for $\mathrm{CON}$ it tended to increase during this period $(P=0.08)$. When cows were lactating, total VFA concentration tended to be higher compared with that during the dry period $(P=0.05)$. Changes in rumen fluid $\mathrm{pH}$ were the inverse of the VFA concentration changes during the dry period and lactation, and $\mathrm{pH}$ was lower during the lactation compared with the dry period $(P<0.01)$. An interaction between treatment and sampling day was observed $(P<0.01)$, and $\mathrm{pH}$ was lower for SUP at $18 \mathrm{~d}$ ap $(6.43 \pm 0.09)$, and higher at $3(6.72 \pm 0.09)$ and $17 \mathrm{~d}$ pp $(6.43 \pm 0.09)(P \leq 0.03)$ compared with CON $(6.83,6.13$, and $5.95 \pm 0.09$ for 18 $\mathrm{d}$ ap, 3 and $17 \mathrm{~d}$ pp, respectively).

Molar proportions (mol/100 mol) of $\mathrm{Ac}, \mathrm{Pr}$, and $\mathrm{Bu}$ (Figure 3B) were affected by sampling day $(P \leq 0.01)$. Generally, the proportion of Ac decreased $(P<0.01)$ after calving, from $72 \pm 0.8 \mathrm{~mol} / 100 \mathrm{~mol}$ during the dry period to $65 \pm 0.8 \mathrm{~mol} / 100 \mathrm{~mol}$ during lactation. Molar proportions of $\mathrm{Pr}$ and $\mathrm{Bu}$ increased accordingly $(P<$ $0.01)$ from $17 \pm 0.9$ and $11 \pm 0.5 \mathrm{~mol} / 100 \mathrm{~mol}$ during the dry period to $23 \pm 0.9$ and $12 \pm 0.5 \mathrm{~mol} / 100 \mathrm{~mol}$ during lactation, respectively. An interaction between treatment and sampling day was observed for the molar proportion of Ac $(P=0.01)$, which tended to be lower at $8 \mathrm{~d}$ ap and higher at $3 \mathrm{~d} p \mathrm{pp}(P=0.06)$ for SUP compared with CON. At 17 and $31 \mathrm{~d}$ pp, molar proportion of Ac was higher in SUP compared with CON $(P \leq$ 0.03). No interaction between treatment and sampling day was observed for the molar proportions of $\operatorname{Pr}(P=$ $0.45)$ and $\mathrm{Bu}(P=0.16)$.

The $k_{\mathrm{a}} \mathrm{Ac}, k_{\mathrm{a}} \mathrm{Pr}, k_{\mathrm{a}} \mathrm{Bu}$, and $k_{\mathrm{l}}$ (Table 5 ) were affected by sampling day $(P \leq 0.03)$. The fractional rates of absorption remained similar throughout the dry period $(P \geq 0.45)$ but increased between 3 and $45 \mathrm{~d}$ pp by $31 \%$ for $k_{\mathrm{a}} \mathrm{Bu}, 49 \%$ for $k_{\mathrm{a}} \mathrm{Pr}$, and $50 \%$ for $k_{\mathrm{a}} \mathrm{Ac}(P<$ $0.01)$. Neither an effect of treatment $(P \geq 0.30)$ nor an interaction between treatment and sampling day was observed $(P \geq 0.73)$ for $k_{\mathrm{a}} \mathrm{Ac}, k_{\mathrm{a}} \mathrm{Pr}$, or $k_{\mathrm{a}} \mathrm{Bu}$. The $k_{\mathrm{a}} \mathrm{Ac}$ and $k_{\mathrm{a}} \mathrm{Pr}$ were greater $(P<0.01)$, and the $k_{\mathrm{a}} \mathrm{Bu}$ tended to be greater $(P=0.09)$ during the lactation than the dry period.

The $k_{1}$ was lower $(P<0.01)$ during the dry period $(0.15 / \mathrm{h})$ compared with lactation $(0.20 / \mathrm{h})$. A tendency

Table 3. Least squares means of blood glucose, nonesterified fatty acids (NEFA), and BHB concentrations for the control (no concentrate during the dry period; CON, $\mathrm{n}=5)$ and supplemental concentrate treatment $\left(3.0 \mathrm{~kg}\right.$ of DM/d concentrate during the dry period; SUP, $\left.\mathrm{n}=4^{1}\right)$

\begin{tabular}{|c|c|c|c|c|c|c|c|c|c|c|c|}
\hline \multirow{2}{*}{ Item } & \multicolumn{7}{|c|}{ Sampling day relative to calving } & \multirow{2}{*}{$\mathrm{SE}^{2}$} & \multicolumn{3}{|c|}{ Fixed effects ${ }^{3}$} \\
\hline & \multicolumn{3}{|c|}{ Dry period } & \multicolumn{4}{|c|}{ Lactation } & & $\mathrm{T}$ & $\mathrm{D}$ & $\mathrm{T} \times \mathrm{D}$ \\
\hline \multicolumn{12}{|c|}{ Glucose, $\mathrm{m} M$} \\
\hline $\mathrm{CON}$ & 3.58 & 3.52 & 3.52 & 3.42 & 3.22 & 3.20 & 3.32 & \multirow[t]{2}{*}{0.157} & \multirow[t]{2}{*}{0.95} & \multirow[t]{2}{*}{0.32} & \multirow[t]{2}{*}{0.98} \\
\hline SUP & 3.78 & 3.63 & 3.58 & 3.18 & 3.13 & 3.23 & 3.35 & & & & \\
\hline \multicolumn{12}{|c|}{ NEFA, $m M$} \\
\hline SUP & 0.28 & 0.22 & 0.30 & 1.66 & 0.79 & 0.82 & 0.58 & 0.108 & 0.57 & $<0.01$ & 0.21 \\
\hline \multicolumn{12}{|c|}{$\mathrm{BHB}, \mathrm{m} M$} \\
\hline $\mathrm{CON}$ & 0.49 & 0.53 & 0.52 & 1.13 & 0.89 & 0.68 & 0.50 & \multirow[t]{2}{*}{0.125} & \multirow[t]{2}{*}{0.54} & \multirow[t]{2}{*}{$<0.01$} & \multirow[t]{2}{*}{0.98} \\
\hline SUP & 0.58 & 0.51 & 0.54 & 1.16 & 0.95 & 0.74 & 0.80 & & & & \\
\hline
\end{tabular}

${ }^{1}$ Group SUP: $\mathrm{n}=4$ (1 cow was removed from the experiment).

${ }^{2} \mathrm{SE}$ for LSM by sampling day; $\mathrm{n}=9$.

${ }^{3} \mathrm{~T}=$ treatment $\mathrm{D}=$ sampling day; $\mathrm{T} \times \mathrm{D}=$ interaction between treatment and sampling day. 
DIEHO ET AL.

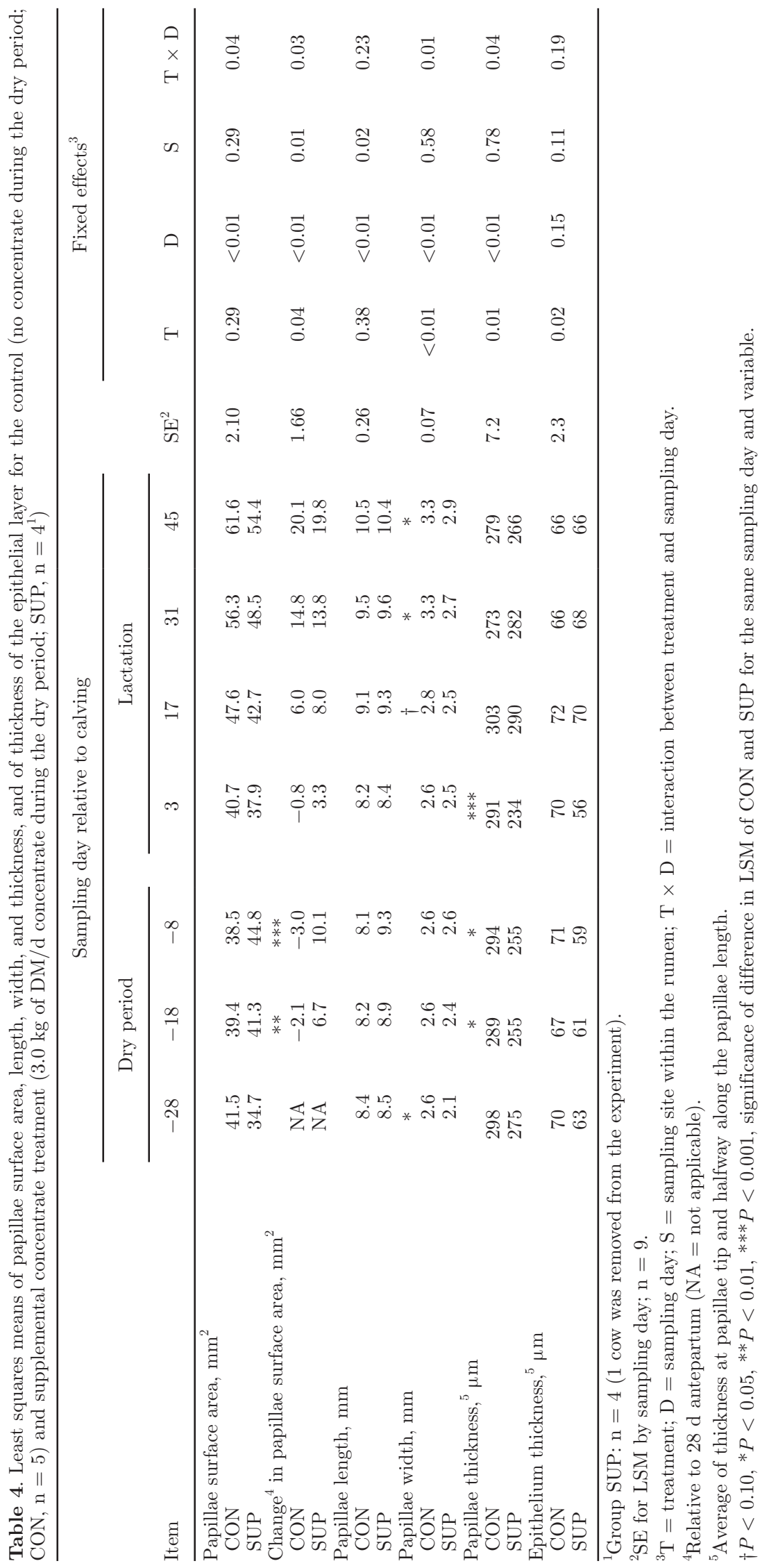


for an interaction between treatment and sampling day was observed $(P=0.06)$. The $k_{1}$ was greater for CON on 31 and $45 \mathrm{~d}$ pp compared with SUP. The $\mathrm{pH}$ of the buffer fluid at the end of the incubation period was affected by sampling day $(P<0.01)$, with the lowest values occurring around calving. Buffer fluid end $\mathrm{pH}$ was also higher when cows were in lactation compared with the dry period $(P<0.01)$, and was generally higher for SUP compared with CON $(P=0.02)$, most notably at $8 \mathrm{~d}$ ap.

\section{DISCUSSION}

The present study provides an overview of the morphological changes of the rumen papillae and changes in ruminal $k_{\mathrm{a}} \mathrm{VFA}$ in periparturient dairy cows with or without supplemental concentrate during the dry period. In line with our hypothesis, dry period concentrate supplementation increased papillae surface area and width. However, by $3 \mathrm{~d}$ pp, these differences had disappeared. Contrary to our expectation, concentrate supplementation during the dry period did not affect $k_{\mathrm{a}} \mathrm{VFA}$ during the dry period or during early lactation.

\section{Feed Intake, Production, BW, and Blood Metabolites}

Unexpectedly, the feeding of supplemental concentrate did not increase DMI during the dry period. Inclusion of supplemental concentrate increased the NFC content and lowered the NDF content per kilogram of total diet DM consumed. Generally, a higher NFC (Holcomb et al., 2001; Rabelo et al., 2003; Overton and Waldron, 2004) and lower NDF (Hayirli et al., 2002) content increases dry period feed intake. In addition, concentrate is not expected to replace a roughagebased ration on a kilogram per kilogram DM basis (NRC, 2001; CVB, 2011). However, a near-complete substitution did occur in SUP during the dry period. Possible explanations might be found in the daily energy intake and composition of the rations in relation to energy requirements. Energy requirement during the last month of gestation approximates 60 (CVB, 2011) to $66 \mathrm{MJ}$ of $\mathrm{NE}_{\mathrm{L}} / \mathrm{d}(\mathrm{NRC}, 2001)$ for a dairy cow $(740$ $\mathrm{kg}$ of BW). Energy intake (71 MJ of $\mathrm{NE}_{\mathrm{L}} / \mathrm{d}$, average of 18 and $8 \mathrm{~d}$ ap) by SUP thus exceeded requirements by 5 to $11 \mathrm{MJ}$ of $\mathrm{NE}_{\mathrm{L}} / \mathrm{d}$ during the last 4 wk of the dry period, whereas energy intake was close to requirement for CON (61 MJ of $\mathrm{NE}_{\mathrm{L}} / \mathrm{d}$, average of 18 and $8 \mathrm{~d}$ ap). The excess energy intake of SUP and glycogenic character of the concentrate might have increased blood leptin and insulin levels, which are known to depress feed intake (Ingvartsen and Andersen, 2000; Ingvartsen and Boisclair, 2001; Chilliard et al., 2005). Greater pal- atability of the concentrate (no refusals of concentrate were observed) might suggest that intake of the dry period ration was relatively decreased. Doepel et al. (2002) likewise did not find an increased DMI with rations with increased nutrient density in the dry period. Intake of DM during the dry period was comparable to that reported by Holcomb et al. (2001), Doepel et al. (2002), and Rabelo et al. (2003). The characteristic periparturient reduction in feed intake was not yet apparent at $8 \mathrm{~d}$ ap. However, inspection of daily feed intake records from $8 \mathrm{~d}$ ap to $3 \mathrm{~d}$ pp showed this decrease for
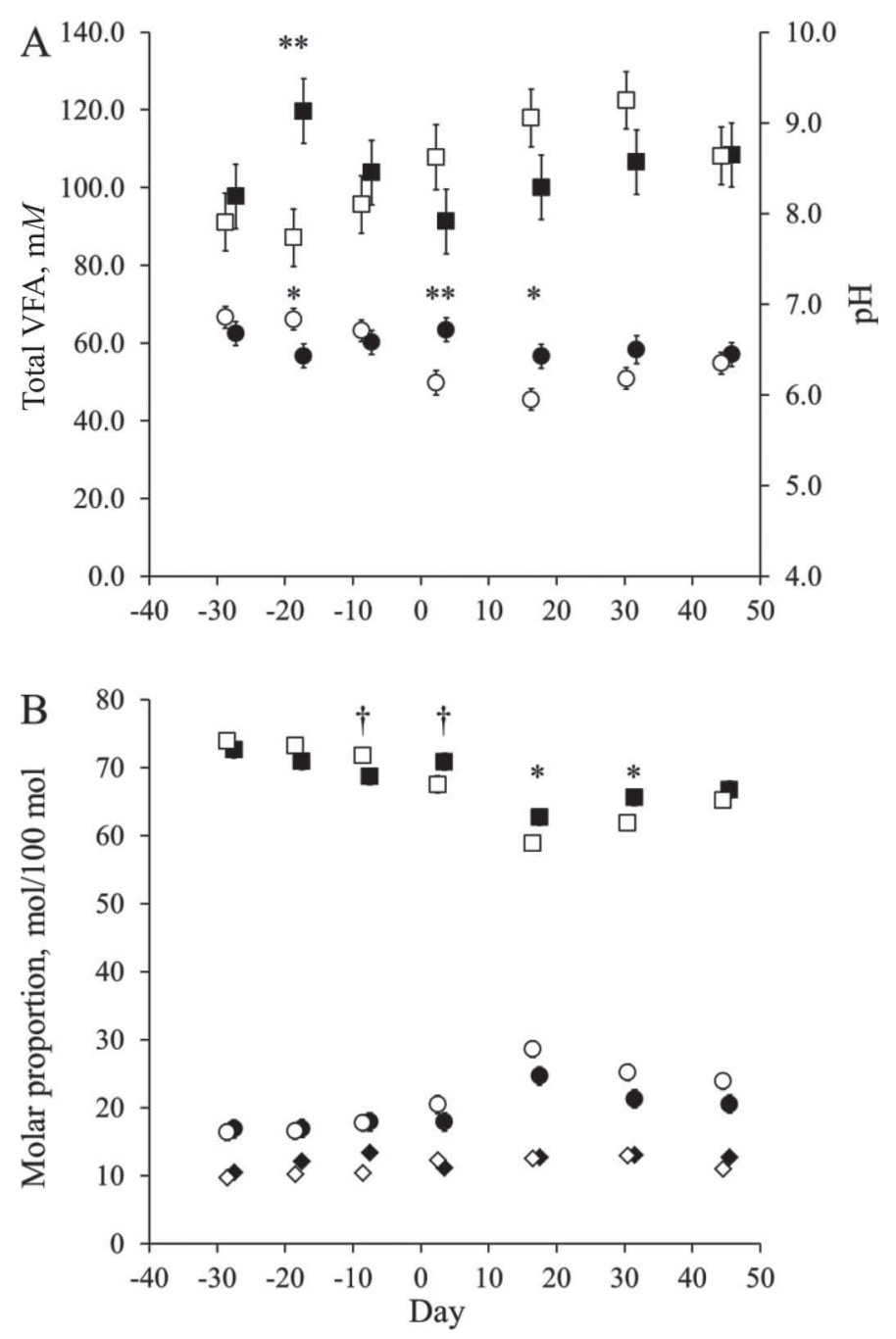

Figure 3. (A) Total VFA concentration $(\square \mathbf{\square})$ and $\mathrm{pH}(\bigcirc)$, and (B) molar proportion of acetic $(\square \mathbf{\square})$, propionic $(\bigcirc)$, and butyric acid $(\diamond \diamond)$ of total VFA in rumen fluid for the control (no concentrate during the dry period; open symbols, $\mathrm{n}=5$ ) and for the dry period treatment with supplemental concentrate $(3.0 \mathrm{~kg}$ of DM/d concentrate during the dry period; solid symbols, $\mathrm{n}=4$ ), and the subsequent lactation period. Values represent $\mathrm{LSM} \pm \mathrm{SE} . \dagger P<0.10,{ }^{*} P<0.05,{ }^{* *} P$ $<0.01$, significance of differences in LSM of CON and SUP for the same sampling day and variable (values are slightly offset for clarity). 
Table 5. Least squares means of the fractional rate of absorption $\left(k_{\mathrm{a}}\right)$ of acetic (Ac), propionic (Pr), and butyric acid $(\mathrm{Bu})$, fractional fluid passage rate $\left(k_{1}\right)$, and buffer fluid end $\mathrm{pH}$ measured using the buffer incubation technique in the empty washed rumen, for the control (no concentrate during the dry period; $\mathrm{CON}, \mathrm{n}=5)$ and supplemental concentrate treatment $(3.0 \mathrm{~kg}$ of DM/d concentrate during the dry period; SUP, $\mathrm{n}=4^{1}$ )

\begin{tabular}{|c|c|c|c|c|c|c|c|c|c|c|c|}
\hline \multirow[b]{3}{*}{ Item } & \multicolumn{7}{|c|}{ Sampling day relative to calving } & \multirow[b]{3}{*}{$\mathrm{SE}^{2}$} & \multicolumn{3}{|c|}{ Fixed effects ${ }^{3}$} \\
\hline & \multicolumn{3}{|c|}{ Dry period } & \multicolumn{4}{|c|}{ Lactation } & & \multirow[b]{2}{*}{$\mathrm{T}$} & \multirow[b]{2}{*}{$\mathrm{D}$} & \multirow[b]{2}{*}{$\mathrm{T} \times \mathrm{D}$} \\
\hline & -28 & -18 & -8 & 3 & 17 & 31 & 45 & & & & \\
\hline \multicolumn{12}{|c|}{$k_{\mathrm{a}} \mathrm{Ac}, / \mathrm{h}$} \\
\hline $\mathrm{CON}$ & 0.26 & 0.28 & 0.30 & 0.27 & 0.34 & 0.39 & 0.45 & \multirow[t]{2}{*}{0.027} & \multirow[t]{2}{*}{0.53} & \multirow[t]{2}{*}{$<0.01$} & \multirow[t]{2}{*}{0.91} \\
\hline SUP & 0.31 & 0.31 & 0.34 & 0.31 & 0.31 & 0.41 & 0.42 & & & & \\
\hline \multicolumn{12}{|c|}{$k_{\mathrm{a}} \operatorname{Pr}, / \mathrm{h}$} \\
\hline $\mathrm{CON}$ & 0.34 & 0.35 & 0.37 & 0.34 & 0.39 & 0.48 & 0.55 & \multirow[t]{2}{*}{0.030} & \multirow[t]{2}{*}{0.33} & \multirow[t]{2}{*}{$<0.01$} & \multirow[t]{2}{*}{0.94} \\
\hline SUP & 0.39 & 0.40 & 0.43 & 0.39 & 0.39 & 0.51 & 0.53 & & & & \\
\hline \multicolumn{12}{|c|}{$k_{\mathrm{a}} \mathrm{Bu}, / \mathrm{h}$} \\
\hline $\mathrm{CON}$ & 0.39 & 0.40 & 0.42 & 0.39 & 0.42 & 0.48 & 0.56 & \multirow[t]{2}{*}{0.028} & \multirow[t]{2}{*}{0.30} & \multirow[t]{2}{*}{0.01} & \multirow[t]{2}{*}{0.73} \\
\hline SUP & 0.46 & 0.43 & 0.48 & 0.46 & 0.41 & 0.52 & 0.55 & & & & \\
\hline \multicolumn{12}{|l|}{$k_{1}, / \mathrm{h}$} \\
\hline $\mathrm{CON}$ & 0.16 & 0.14 & 0.12 & 0.23 & 0.18 & 0.27 & 0.23 & \multirow[t]{2}{*}{0.020} & \multirow[t]{2}{*}{0.14} & \multirow[t]{2}{*}{0.03} & \multirow[t]{2}{*}{0.06} \\
\hline SUP & 0.16 & 0.16 & 0.16 & 0.22 & 0.20 & 0.17 & 0.13 & & & & \\
\hline \multicolumn{12}{|c|}{ Buffer fluid end $\mathrm{pH}$} \\
\hline $\mathrm{CON}$ & 7.14 & 7.11 & 6.86 & 7.03 & 7.05 & 7.27 & 7.35 & \multirow[t]{2}{*}{0.056} & \multirow[t]{2}{*}{0.02} & \multirow[t]{2}{*}{$<0.01$} & \multirow[t]{2}{*}{0.10} \\
\hline SUP & 7.17 & 7.18 & 7.18 & 7.10 & 7.15 & 7.23 & 7.28 & & & & \\
\hline
\end{tabular}

${ }^{1}$ Group SUP: $\mathrm{n}=4$ (1 cow was removed from the experiment).

${ }^{2} \mathrm{SE}$ for LSM by sampling day; $\mathrm{n}=9$.

${ }^{3} \mathrm{~T}=$ treatment $\mathrm{D}=$ sampling day; $\mathrm{T} \times \mathrm{D}=$ interaction between treatment and sampling day.

both SUP and CON, with an average intake of 9.9 and $9.2 \mathrm{~kg}$ of $\mathrm{DM} / \mathrm{d}$ during 3 to $1 \mathrm{~d}$ ap, respectively. In contrast to Doepel et al. (2002), but in line with Holcomb et al. (2001), Ingvartsen et al. (2001), and Reynolds et al. (2004), no effect of ap treatment on pp feed intake was found and feed intake was, compared with CON, only numerically lower in SUP at $3 \mathrm{~d}$ pp. Treatment contrasts (when compared on a $\mathrm{NE}_{\mathrm{L}}$ or $\mathrm{CP}$ basis) as applied by Doepel et al. (2002) were greater than in the present study and might explain the different effects of the ap treatment on pp DMI. Although DMI was not affected by supplemental concentrate, sugar intake was approximately doubled and FOM intake was 25 and $9 \%$ greater (numerically only) with SUP than CON at 18 and $8 \mathrm{~d}$ ap, respectively. Supplemental concentrate reduced rumen $\mathrm{pH}$, increased VFA concentrations, and induced rumen papillae growth during the dry period.

In line with Holcomb et al. (2001), Ingvartsen et al. (2001), Doepel et al. (2002), and Rabelo et al. (2003; multiparous cows only), feeding concentrate during the dry period had no effect on milk yield or milk fat and protein contents in the subsequent lactation. The numerical increase in BW of SUP compared with CON during the dry period agrees with the numerically higher energy intake of SUP. The decrease in BW after calving corresponds with the negative energy balance typically seen during early lactation. The treatment did not affect ap and pp blood NEFA, BHB, or glucose concentrations, which were within the range reported by earlier studies (VandeHaar et al., 1999; Holcomb et al., 2001; Kokkonen et al., 2004). Notably, no blood BHB concentrations above the clinical ketosis threshold $(>3.0 \mathrm{mM})$ were found, whereas 8 out of 63 collected samples were above the subclinical ketosis threshold (>1.2 mM; McArt et al., 2012); namely, 4 samples from CON ( 3 cows at $3 \mathrm{~d} \mathrm{pp}, 1$ cow at $17 \mathrm{~d} \mathrm{pp}$ ) and 4 from SUP ( 1 cow at $3 \mathrm{~d}$ pp, and 1 cow at 3,17 , and $45 \mathrm{~d}$ pp). Therefore, supplemental concentrate during the dry period did not appear to affect the milk production and metabolic status of cows in the subsequent lactation, although caution is warranted given the relatively small number of cows used.

\section{Morphological Changes of the Rumen Papillae}

Despite the limited effect of supplemental concentrate on nutrient intake during the dry period, papillae surface area was increased, supporting the earlier studies in dry cows by Dirksen et al. (1984) and Liebich et al. (1987). In contrast, Andersen et al. (1999), Rabelo et al. (2001), and Reynolds et al. (2004) did not report proliferative effects of dry period treatments on rumen papillae. However, clear differences in approach and methodology can be identified. Andersen et al. (1999) applied a "VFA load strategy," feeding $3.9 \mathrm{~kg}$ of DM rolled barley in the morning and grass silage in the afternoon compared with a control ration of grass silage and $0.8 \mathrm{~kg}$ of concentrate divided between the morning 
and afternoon. No differences in nutrient intake existed and the treatment was applied for 4 wk before collecting papillae. This strategy succeeded in affecting rumen fluid composition, increasing the total VFA, $\mathrm{Pr}$, and $\mathrm{Bu}$ concentrations in the VFA load group, but did not affect rumen papillae morphology. Reynolds et al. (2004) fed $0.80 \mathrm{~kg}$ of $\mathrm{DM} / \mathrm{d}$ of supplemental barley or $0.75 \mathrm{~kg}$ of $\mathrm{DM} / \mathrm{d}$ of supplemental soybean protein compared with a nonsupplemented dry period ration starting 6 wk before calving. Unexpectedly, the barley treatment coincided with a smaller papillae width and surface area compared with nonsupplemented cows, which was attributed to genetic or previous environmental influences. It can be argued that the treatment contrasts imposed by Andersen et al. (1999) and Reynolds et al. (2004) were too minor to induce papillae proliferation. Rabelo et al. (2001) fed low-energy (6.3 $\mathrm{MJ}$ of $\mathrm{NE}_{\mathrm{L}} / \mathrm{kg}$ of $\mathrm{DM}$ ) or high-energy (6.9 MJ of $\mathrm{NE}_{\mathrm{L}} / \mathrm{kg}$ of $\mathrm{DM}$ ) rations with a marked difference in concentrate to roughage ratio for $3 \mathrm{wk}$ before collection of papillae, resulting in a treatment contrast $\left(0.6 \mathrm{MJ}\right.$ of $\mathrm{NE}_{\mathrm{L}} / \mathrm{kg}$ of $\left.\mathrm{DM}\right)$ comparable to that in the current experiment. In contrast to the present study, they found only a tendency for longer papillae in the ventral rumen when feeding the high-energy ration. In addition, Reynolds et al. (2004) did not observe a change in papillae dimensions (length, width, surface area) when comparing the dry period (21 and $7 \mathrm{~d}$ ap) with early lactation (10 and 22 d pp). Crucially, Andersen et al. (1999), Rabelo et al. (2001), and Reynolds et al. (2004) all made end-point measurements compared with repeated measurements on the same animal, as was done in the present study and by Dirksen et al. (1984), Liebich et al. (1987), and Dieho et al. (2016a). Substantial variation in papillae morphology between animals is commonly found (Reynolds et al., 2004; Dieho et al., 2016a), and this underlines the importance of a repeated-measurements approach for studying changes in rumen morphology over time. A minimum of 8 papillae per site per cow per sampling day were used for macroscopic measurements, and 5 papillae per site per cow per sampling day were used for microscopic measurements; these numbers are in general agreement with previous work (Odongo et al., 2006; Steele et al., 2011, 2015). The large variation in papillae morphology between individual animals is also illustrated by the present study, where papillae surface area appeared to be (numerically) $20 \%$ greater for CON compared with SUP at $28 \mathrm{~d}$ ap, the first day of the treatment. This was likely the result of inherent differences between individual cows. A treatment $x$ sampling day interaction indicated differences in surface area development between CON and SUP. After correction for differences in papillae characteristics of individual cows, concentrate supplementation during the dry period increased papillae surface area compared with the control. In addition, the increase in papillae surface area during lactation (independent of treatment during dry period) was also clearly shown. This experiment thus confirms the repeated-measurements approach as viable for studying morphological changes to the rumen wall.

The observed postpartum increase in papillae size generally corresponded to earlier work (Liebich et al., 1987; Dieho et al., 2016a). However, the decrease in papillae surface area between $8 \mathrm{~d}$ ap and $3 \mathrm{~d}$ pp in SUP was not expected and contrasts with data reported by Liebich et al. (1987), where the gains in papillae size made during the dry period carried over into the lactation. No decrease was found for CON between $8 \mathrm{~d}$ ap and $3 \mathrm{~d}$ pp, and Dieho et al. (2016a) found only a numerical $\left(2.2 \mathrm{~mm}^{2}\right)$ reduction between $10 \mathrm{~d}$ ap and 3 d pp. Papillae atrophy when cows switch to a lower feeding level (Dirksen et al., 1984). The decrease in papillae surface area in SUP between $8 \mathrm{~d}$ ap and $3 \mathrm{~d}$ pp may therefore be explained by the peripartum depression in FOM intake, as observed at $3 \mathrm{~d}$ pp compared with $8 \mathrm{~d}$ ap. The reduction in papillae surface area was most pronounced in the ventral blind rumen sac. Capillary blood flow in the ventral parts of the rumen is also reported to be approximately twice that of the dorsal regions (Von Engelhardt and Hales, 1977), and is therefore suggested to be responsible for a major part of total VFA absorption capacity. We can therefore speculate that this active part of the rumen mucosa is more sensitive to changes in rumen fluid composition (decreased total VFA, increase in $\mathrm{pH}$ ) as observed for SUP around calving. Alternatively, it can be speculated that the larger papillae induced by the supplemental concentrate are more sensitive to the peripartum decrease in feed intake. Increasing the concentrate allowance between $8 \mathrm{~d}$ ap and $3 \mathrm{~d}$ pp might have prevented the decrease, as this likely maintained the higher VFA concentrations and lower $\mathrm{pH}$.

\section{Rumen Fluid Composition and Fractional VFA Absorption Rate}

Feeding supplemental concentrate increased rumen fluid VFA concentration, lowered $\mathrm{pH}$, and tended to affect molar proportions of $\mathrm{Ac}, \mathrm{Pr}$, and $\mathrm{Bu}$ during the dry period, as expected (Rabelo et al., 2001; Bannink et al., 2006). However, treatment effects on VFA concentration and $\mathrm{pH}$ were only apparent at $18 \mathrm{~d}$ ap and not at $8 \mathrm{~d}$ ap. At $18 \mathrm{~d}$ ap, this might be explained by a numerically higher FOM intake for SUP. At 8 d ap, FOM intake was similar to that at $18 \mathrm{~d}$ ap for SUP, 
but rumen fluid $\mathrm{pH}$ was higher and VFA concentration lower than at $18 \mathrm{~d}$ ap. This seems to suggest an adaptive response in SUP. However, only minor numerical increases in the capacity for VFA absorption between 18 and $8 \mathrm{~d}$ ap were observed, offering little support for an adaptive response. The difference in $\mathrm{pH}$ between SUP and CON at $3 \mathrm{~d}$ pp might be explained by the numerical difference in FOM intake. However, the difference in $\mathrm{pH}$ between SUP and CON at $17 \mathrm{~d}$ cannot be explained by a difference in FOM intake - no such difference was observed at $17 \mathrm{~d}$ pp. Whereas this arguably better buffering capacity of SUP at 3 and $17 \mathrm{~d}$ pp might be attributed to the dry period treatment, the $\mathrm{pH}$ and VFA concentration data should be interpreted with caution. Sampling of rumen fluid was not frequent (once a day) and not strictly standardized relative to last access to feed, meal size, and meal composition. Thus, observed differences in $\mathrm{pH}$ and VFA concentrations are not fully representative for the daily averages of treatment effects.

The $k_{\mathrm{a}} \mathrm{Ac}, k_{\mathrm{a}} \mathrm{Pr}$, and $k_{\mathrm{a}} \mathrm{Bu}$ from the dry period and $3 \mathrm{~d}$ pp in the present study largely agree with those reported earlier by Dieho et al. (2016b) for similar sampling days using an identical incubation technique and buffer composition. The $k_{\mathrm{a}} \mathrm{Ac}, k_{\mathrm{a}} \mathrm{Pr}$, and $k_{\mathrm{a}} \mathrm{Bu}$ observed in the present study from $17 \mathrm{~d}$ pp onward are lower than those reported by Dieho et al. (2016b), but both our current and previous studies show a clear increase in $k_{\mathrm{a}} \mathrm{VFA}$ early postpartum. Greater intake of DM and FOM as reported by Dieho et al. (2016b) compared with the present study might have affected $k_{\mathrm{a}} \mathrm{VFA}$. In contrast to our expectations, the $k_{\mathrm{a}} \mathrm{VFA}$ for SUP did not increase with the increase in papillae surface area during the dry period. This apparently contradicts the classic study by Dirksen et al. (1984), who observed an increase in VFA absorption in dry cows concomitant with increase in papillae surface area. The contradiction with Dirksen et al. (1984) is likely the result of differences in treatment contrasts. Dirksen et al. (1984) nearly doubled the $\mathrm{NE}_{\mathrm{L}}$ intake from 47 to $86 \mathrm{MJ} / \mathrm{d}$. In order of magnitude, this is similar to the difference between the dry period and lactation intake in the present experiment, for which a clear increase in $k_{\mathrm{a}} \mathrm{VFA}$ was found. It should be noted that the BIT technique reflects the capacity of the rumen to absorb VFA under standardized conditions. Fractional absorption rates of VFA obtained using the BIT technique do not necessarily reflect those during the actual physiological conditions at time of measurement (Dieho et al., 2016b).

In our previous experiment (Dieho et al., 2016b) in early lactation, we observed a similar lack of increase in $k_{\mathrm{a}} \mathrm{VFA}$ with a temporary increase in rumen papillae surface area in response to a more rapid increase of the rate of increase of concentrate allowance. It is unlikely that the lack of effect of greater papillae surface area on $k_{\mathrm{a}} \mathrm{VFA}$ can be explained by a decreased capacity for $k_{\mathrm{a}} \mathrm{VFA}$ per unit of surface area (Sehested et al., 2000; Etschmann et al., 2009; Schurmann et al., 2014). However, epithelial blood flow has been shown to affect VFA absorption, and this might be a limiting factor for VFA absorption (Storm et al., 2011). Two independent mechanisms might be involved. First, a limited epithelial blood flow likely coincides with an increase in blood VFA concentration in the papilla capillaries. This decreases the concentration gradient between blood and VFA in the epithelium, and the intracellular accumulation of VFA in turn limits the concentration gradient with the rumen fluid (Storm et al., 2011). Second, exchange of $\mathrm{VFA}^{-}$(dissociated VFA) for $\mathrm{HCO}_{3}^{-}$has been shown to play an important role in VFA absorption and is arguably responsible for $>50 \%$ of VFA uptake (Aschenbach et al., 2011). The major part of the $\mathrm{HCO}_{3}{ }^{-}$required for this exchange derives from extracellular (extra-epithelial) sources (Aschenbach et al., 2009) and is therefore not associated with formation of $\mathrm{HCO}_{3}{ }^{-}$by carbon-anhydrase from $\mathrm{CO}_{2}$. A limited supply of $\mathrm{HCO}_{3}{ }^{-}$via the epithelial blood flow might therefore limit the capacity for VFA uptake. The large increase in epithelial blood flow after calving (Reynolds et al., 2003) might both aid maintenance of concentration gradients and increase the supply of $\mathrm{HCO}_{3}{ }^{-}$, thereby increasing the capacity for VFA absorption as observed. However, ruminal blood flow is also subjected to diurnal variation and postprandial effects such as rumen fluid composition (Von Engelhardt and Hales, 1977; Storm and Kristensen 2010). Future studies are required to fully elucidate the role of epithelial blood flow and $\mathrm{HCO}_{3}{ }^{-}$on the ruminal VFA absorption capacity.

\section{CONCLUSIONS}

The dry period and lactation feed and energy intakes, blood glucose, NEFA, and BHB concentrations, and milk yield and milk composition were not affected by feeding supplemental concentrate during the dry period. Feeding supplemental concentrate during the dry period increased papillae surface area during the dry period without a concomitant increase in $k_{\mathrm{a}} \mathrm{VFA}$. The increased papillae surface area in the dry period was not maintained into the subsequent lactation period, and $k_{\mathrm{a}} \mathrm{VFA}$ in the lactation period was not affected by the dry period concentrate supplement. Thus, our results indicate that feeding supplemental concentrate during the dry period, although increasing papillae surface area during this period, did not positively affect papillae surface area and $k_{\mathrm{a}} \mathrm{VFA}$ during subsequent early lactation. 


\section{ACKNOWLEDGMENTS}

The authors acknowledge the Dairy Campus staff (Lelystad, the Netherlands) for their technical support, and Rosaline van Hien (Wageningen, the Netherlands) and Danjella Nanninga (Utrecht, the Netherlands) for their assistance during the sampling procedures. The authors acknowledge the financial support of the Product Board Animal Feed (Zoetermeer, the Netherlands) and Dutch Dairy Board (Zoetermeer, the Netherlands).

\section{REFERENCES}

Andersen, J. B., J. Sehested, and K. L. Ingvartsen. 1999. Effect of dry cow feeding strategy on rumen $\mathrm{pH}$, concentration of volatile fatty acids and rumen epithelium development. Acta Agric. Scand. Anim. Sci. 49:149-155. https://doi.org/10.1080/090647099424051.

Aschenbach, J. R., S. Bilk, G. Tadesse, F. Stumpff, and G. Gäbel. 2009. Bicarbonate-dependent and bicarbonate-independent mechanisms contribute to nondiffusive uptake of acetate in the ruminal epithelium of sheep. Am. J. Physiol. Gastrointest. Liver Physiol. 296:G1098-G1107. https://doi.org/10.1152/ajpgi.90442.2008.

Aschenbach, J. R., G. B. Penner, F. Stumpff, and G. Gäbel. 2011. Ruminant nutrition symposium: Role of fermentation acid absorption in the regulation of ruminal pH. J. Anim. Sci. 89:1092-1107. https://doi.org/10.2527/jas.2010-3301.

Bannink, A., J. Dijkstra, S. J. Koopmans, and Z. Mroz. 2006. Physiology, regulation and multifunctional activity of the gut wall: A rationale for multicompartmental modelling. Nutr. Res. Rev. 19:227-253. https://doi.org/10.1017/S0954422407334094.

Bannink, A., W. J. J. Gerrits, J. France, and J. Dijkstra. 2012. Variation in rumen fermentation and the rumen wall during the transition period in dairy cows. Anim. Feed Sci. Technol. 172:80-94. https://doi.org/10.1016/j.anifeedsci.2011.12.010.

Bergman, E. N. 1990. Energy contributions of volatile fatty acids from the gastrointestinal tract in various species. Physiol. Rev. 70:567-590.

Chilliard, Y., C. Delavaud, and M. Bonnet. 2005. Leptin expression in ruminants: Nutritional and physiological regulations in relation with energy metabolism. Domest. Anim. Endocrinol. 29:3-22. https://doi.org/10.1016/j.domaniend.2005.02.026.

CVB. 2011. Chemische samenstellingen en nutritionele waarden van voedermiddelen (in Dutch). CVB (Centraal Veevoederbureau), The Hague, the Netherlands.

Dieho, K., A. Bannink, I. A. L. Geurts, J. T. Schonewille, G. Gort, and J. Dijkstra. 2016a. Morphological adaptation of rumen papillae during the dry period and early lactation as affected by rate of increase of concentrate allowance. J. Dairy Sci. 99:2339-2352. https://doi.org/10.3168/jds.2015-9837.

Dieho, K., J. Dijkstra, J. T. Schonewille, and A. Bannink. 2016b. Changes in ruminal volatile fatty acid production and absorption rate during the dry period and early lactation as affected by rate of increase of concentrate allowance. J. Dairy Sci. 99:5370-5384. https://doi.org/10.3168/jds.2015-10819.

Dijkstra, J., H. Boer, J. Van Bruchem, M. Bruining, and S. Tamminga. 1993. Absorption of volatile fatty acids from the rumen of lactating dairy cows as influenced by volatile fatty acid concentration, pH and rumen liquid volume. Br. J. Nutr. 69:385-396. https://doi. org/10.1079/BJN19930041.

Dijkstra, J., J. L. Ellis, E. Kebreab, A. B. Strathe, S. López, J. France, and A. Bannink. 2012. Ruminal pH regulation and nutritional consequences of low pH. Anim. Feed Sci. Technol. 172:22-33. https:// doi.org/10.1016/j.anifeedsci.2011.12.005.

Dirksen, G., H. G. Liebich, G. Brosi, H. Hagemeister, and E. Mayer. 1984. Morphologie der Pansenschleimhaut und Fettsäureresorption beim Rind - bedeutende Faktoren für Gesundheit und Leistung. Zentralbl. Veterinarmed. A 31:414-430. https://doi. org/10.1111/j.1439-0442.1984.tb01300.x.
Dirksen, G. U., H. G. Liebich, and E. Mayer. 1985. Adaptive changes of the ruminal mucosa and their functional and clinical significance. Bovine Pract 20:116-120.

Doepel, L., H. Lapierre, and J. J. Kennelly. 2002. Peripartum performance and metabolism of dairy cows in response to prepartum energy and protein intake. J. Dairy Sci. 85:2315-2334. https://doi. org/10.3168/jds.S0022-0302(02)74312-9.

Etschmann, B., A. Suplie, and H. Martens. 2009. Change of ruminal sodium transport in sheep during dietary adaptation. Arch. Anim. Nutr. 63:26-38. https://doi.org/10.1080/17450390802506885.

Gäbel, G., J. R. Aschenbach, and F. Müller. 2002. Transfer of energy substrates across the ruminal epithelium: Implications and limitations. Anim. Health Res. Rev. 3:15-30. https://doi.org/10.1079/ AHRR200237.

Hayirli, A., R. R. Grummer, E. V. Nordheim, and P. M. Crump. 2002. Animal and dietary factors affecting feed intake during the prefresh transition period in Holsteins. J. Dairy Sci. 85:3430-3443. https://doi.org/10.3168/jds.S0022-0302(02)74431-7.

Holcomb, C. S., H. H. Van Horn, H. H. Head, M. B. Hall, and C. J. Wilcox. 2001. Effects of prepartum dry matter intake and forage percentage on postpartum performance of lactating dairy cows. J. Dairy Sci. 84:2051-2058. https://doi.org/10.3168/jds.S00220302(01) 74649-8.

Ingvartsen, K. L., O. Aaes, and J. B. Andersen. 2001. Effects of pattern of concentrate allocation in the dry period and early lactation on feed intake and lactational performance in dairy cows. Livest. Prod. Sci. 71:207-221. https://doi.org/10.1016/S03016226(01)00192-0.

Ingvartsen, K. L., and J. B. Andersen. 2000. Integration of metabolism and intake regulation: A review focusing on periparturient animals. J. Dairy Sci. 83:1573-1597. https://doi.org/10.3168/jds. S0022-0302(00)75029-6.

Ingvartsen, K. L., and Y. R. Boisclair. 2001. Leptin and the regulation of food intake, energy homeostasis and immunity with special focus on periparturient ruminants. Domest. Anim. Endocrinol. 21:215-250. https://doi.org/10.1016/S0739-7240(02)00119-4.

ISO. 1999. Whole milk. Determination of milk fat, protein and lactose content-Guidance on the operation of mid-infrared instruments. ISO 9622. International Organization for Standardization (ISO), Geneva, Switzerland.

Kokkonen, T., A. Tesfa, M. Tuori, and L. Syrjälä-Qvist. 2004. Concentrate feeding strategy of dairy cows during transition period. Livest. Prod. Sci. 86:239-251. https://doi.org/10.1016/j. livprodsci.2003.09.003.

Krause, K. M., and G. R. Oetzel. 2006. Understanding and preventing subacute ruminal acidosis in dairy herds: A review. Anim. Feed Sci. Technol. 126:215-236. https://doi.org/10.1016/j. anifeedsci.2005.08.004

Liebich, H. G., G. Dirksen, A. Arbel, S. Dori, and E. Mayer. 1987. Fütterungsabhängige Veränderungen der Pansenschleimhaut von Hochleistungskühen im Zeitraum von der Trockenstellung bis acht Wochen postpartum. J. Vet. Med. Ser. A 34:661-672. https://doi. org/10.1111/j.1439-0442.1987.tb00329.x.

Littell, R. C., P. R. Henry, and C. B. Ammerman. 1998. Statistical analysis of repeated measures data using SAS procedures. J. Anim. Sci. 76:1216-1231.

Littell, R. C., G. A. Milliken, W. W. Stroup, R. D. Wolfinger, and O. Schabenberger. 2006. SAS for Mixed Models. 2nd ed. SAS Institute Inc., Gary, NC.

McArt, J. A. A., D. V. Nydam, and G. R. Oetzel. 2012. Epidemiology of subclinical ketosis in early lactation dairy cattle. J. Dairy Sci. 95:5056-5066. https://doi.org/10.3168/jds.2012-5443.

Melo, L. Q., S. F. Costa, F. Lopes, M. C. Guerreiro, L. E. Armentano, and M. N. Pereira. 2013. Rumen morphometrics and the effect of digesta $\mathrm{pH}$ and volume on volatile fatty acid absorption. J. Anim. Sci. 91:1775-1783. https://doi.org/10.2527/jas.2011-4999.

Mentschel, J., R. Leiser, C. Mülling, C. Pfarrer, and R. Claus. 2001. Butyric acid stimulates rumen mucosa development in the calf mainly by a reduction of apoptosis. Arch. Tierernahr. 55:85-102. https://doi.org/10.1080/17450390109386185. 
NRC. 2001. Nutrient Requirements of Dairy Cattle. 7th rev. ed. Natl. Acad. Press, Washington, DC.

Odongo, N. E., O. AlZahal, M. I. Lindinger, T. F. Duffield, E. V. Valdes, S. P. Terrell, and B. W. McBride. 2006. Effects of mild heat stress and grain challenge on acid-base balance and rumen tissue histology in lambs. J. Anim. Sci. 84:447-455.

Overton, T. R., and M. R. Waldron. 2004. Nutritional management of transition dairy cows: Strategies to optimize metabolic health. J. Dairy Sci. 87(E-Suppl.):E105-E119. https://doi.org/10.3168/jds. S0022-0302(04)70066-1.

Penner, G. B., J. R. Aschenbach, G. Gäbel, R. Rackwitz, and M. Oba 2009. Epithelial capacity for apical uptake of short chain fatty acids is a key determinant for intraruminal $\mathrm{pH}$ and the susceptibility to subacute ruminal acidosis in sheep. J. Nutr. 139:1714-1720. https://doi.org/10.3945/jn.109.108506.

Rabelo, E., S. J. Bertics, J. Mackovic, and R. R. Grummer. 2001. Strategies for increasing energy density of dry cow diets. J. Dairy Sci 84:2240-2249. https://doi.org/10.3168/jds.S0022-0302(01)746711.

Rabelo, E., R. L. Rezende, S. J. Bertics, and R. R. Grummer. 2003. Effects of transition diets varying in dietary energy density on lactation performance and ruminal parameters of dairy cows. J. Dairy Sci. 86:916-925. https://doi.org/10.3168/jds.S00220302(03)73674-1.

Reynolds, C. K., P. C. Aikman, B. Lupoli, D. J. Humphries, and D. E. Beever. 2003. Splanchnic metabolism of dairy cows during the transition from late gestation through early lactation. J. Dairy Sci. 86:1201-1217. https://doi.org/10.3168/jds.S0022-0302(03)737047.

Reynolds, C. K., B. Durst, B. Lupoli, D. J. Humphries, and D. E. Beever. 2004. Visceral tissue mass and rumen volume in dairy cows during the transition from late gestation to early lactation. J. Dairy Sci. 87:961-971. https://doi.org/10.3168/jds.S00220302(04)73240-3.

Schurmann, B. L., M. E. Walpole, P. Górka, J. C. H. Ching, M. E. Loewen, and G. B. Penner. 2014. Short-term adaptation of the ruminal epithelium involves abrupt changes in sodium and short-chain fatty acid transport. Am. J. Physiol. Regul. Integr. Comp. Physiol. 307:R802-R816. https://doi.org/10.1152/ ajpregu.00035.2014

Sehested, J., J. B. Andersen, O. Aaes, N. B. Kristensen, L. Diernæs, P. D. Møller, and E. Skadhauge. 2000. Feed-induced changes in the transport of butyrate, sodium and chloride ions across the isolated bovine rumen epithelium. Acta Agric. Scand. Anim. Sci. 50:47-55. https://doi.org/10.1080/090647000423924.

Steele, M. A., J. Croom, M. Kahler, O. AlZahal, S. E. Hook, K. Plaizier, and B. W. McBride. 2011. Bovine rumen epithelium under- goes rapid structural adaptations during grain-induced subacute ruminal acidosis. Am. J. Physiol. Regul. Integr. Comp. Physiol. 300:R1515-R1523. https://doi.org/10.1152/ajpregu.00120.2010.

Steele, M. A.. C. Schiestel, O. AlZahal, L. Dionissopoulos, A. H. Laarman, J. C. Matthews, and B. W. McBride. 2015. The periparturient period is associated with structural and transcriptomic adaptations of rumen papillae in dairy cattle. J. Dairy Sci. 98:2583-2595. https://doi.org/10.3168/jds.2014-8640.

Storm, A. C., M. D. Hanigan, and N. B. Kristensen. 2011. Effects of ruminal ammonia and butyrate concentrations on reticuloruminal epithelial blood flow and volatile fatty acid absorption kinetics under washed reticulorumen conditions in lactating dairy cows. J. Dairy Sci. 94:3980-3994. https://doi.org/10.3168/jds.2010-4091.

Storm, A. C., and N. B. Kristensen. 2010. Effects of particle size and dry matter content of a total mixed ration on intraruminal equilibration and net portal flux of volatile fatty acids in lactating dairy cows. J. Dairy Sci. 93:4223-4238. https://doi.org/10.3168/ jds.2009-3002.

Tamminga, S., W. M. Van Straalen, A. P. J. Subnel, R. G. M. Meijer, A. Steg, C. J. G. Wever, and M. C. Blok. 1994. The Dutch protein evaluation system: The DVE/OEB-system. Livest. Prod. Sci. 40:139-155. https://doi.org/10.1016/0301-6226(94)90043-4.

Thorlacius, S. O., and G. A. Lodge. 1973. Absorption of steam-volatile fatty acids from the rumen of the cow as influenced by diet, buffers and pH. Can. J. Anim. Sci. 53:279-288. https://doi.org/10.4141/ cjas73-044.

Udén, P., P. E. Colucci, and P. J. Van Soest. 1980. Investigation of chromium, cerium and cobalt as markers in digesta. Rate of passage studies. J. Sci. Food Agric. 31:625-632. https://doi.org/10.1002/ jsfa.2740310702.

van Es, A. J. H. 1978. Feed evaluation for ruminants. I. The systems in use from May 1977 onwards in The Netherlands. Livest. Prod. Sci. 5:331-345. https://doi.org/10.1016/0301-6226(78)90029-5.

van Knegsel, A. T. M., H. van den Brand, J. Dijkstra, W. M. van Straalen, R. Jorritsma, S. Tamminga, and B. Kemp. 2007. Effect of glucogenic vs. lipogenic diets on energy balance, blood metabolites, and reproduction in primiparous and multiparous dairy cows in early lactation. J. Dairy Sci. 90:3397-3409. https://doi. org/10.3168/jds.2006-837.

VandeHaar, M. J., G. Yousif, B. K. Sharma, T. H. Herdt, R. S. Emery, M. S. Allen, and J. S. Liesman. 1999. Effect of energy and protein density of prepartum diets on fat and protein metabolism of dairy cattle in the periparturient period. J. Dairy Sci. 82:1282-1295. https://doi.org/10.3168/jds.S0022-0302(99)75351-8.

Von Engelhardt, W. V., and J. R. Hales. 1977. Partition of capillary blood flow in rumen, reticulum, and omasum of sheep. Am. J. Physiol. 232:E53-E56. 